2. Rajapaksa US, Ihalamulla RL, Udagedera C, Karunaweera ND. Cutaneous leishmaniasis in southern Sri Lanka. Transactions of the Royal Society of Tropical Medicine and Hygiene 2007; 101: 799-803.

3. Ranawaka RR, Weerakoon HS, Opathella N, Subasinghe C. Leishmaniasis in North Central Province. Sri Lanka - three years' experiences. The Sri Lanka Journal of Dermatology 2010; 14: 4-8.

4. Siriwardana HVYD, Noyes HA, Beeching NJ, Chance ML, Karunaweera ND, Bates PA. Leishmania donovani and cutaneous leishmaniasis, Sri Lanka. Emerging Infectious Disease 2007; 13: 476-8.

5. Karunaweera ND, Pratlong F, Siriwardane HVYD, Ihalamulla RL, Dejet JP. Cutaneous leishmaniasis is caused by Leishmania donovani zymodeme MON-37. Transactions of the Royal Society of Tropical Medicine and Hygiene 2003; 97: 380-1.

6. ul Bari A, ber Rahman S. Correlation of clinical, histopathological, and microbiological findings in 60 cases of cutaneous leishmaniasis. Indian Journal of Dermatology, Venereology and Leprology 2006; 72: 28-32.

7. Al-Hucheimi SN, Sultan BA, Al-Dhalimi MA. A comparative study of the diagnosis of Old World cutaneous leishmaniasis in Iraq by polymerase chain reaction and microbiologic and histopathologic methods. International Journal of Dermatology 2009; 48: 404-8.

8. Herath $\mathrm{CH}$, Ratnatunga NV, Waduge R, Ratnayake P,
Ratnatunga CN, Ramadasa S. A histopathological study of cutaneous leishmaniasis in Sri Lanka. Ceylon Medical Journal 2010; 55: 106-11.

9. Ranawaka RR, Weerakoon HS. Randomised, double blind, comparative clinical trial on efficacy and safety of intralesional sodium stibogluconate and intralesional 7\% hypertonic sodium chloride against cutaneous leishmaniasis caused by L. donovani. Journal of Dermatologic Treatment 2010; 21: 286-93.

10. Ranawaka RR, Weerakoon HS, Opathella N. Liquid nitrogen cryotherapy on Leishmania donovani cutaneous leishmaniasis. Journal of Dermatologic Treatment 2011; 22: 241-5.

11. Marques MJ, Volpini AC, Machado-Coelho GL, MachadoPinto J, da Costa CA, Mayrink W, Genaro O, Romanha AJ. Comparison of polymerase chain reaction with other laboratory methods for the diagnosis of American cutaneous leishmaniasis: diagnosis of cutaneous leishmaniasis by polymerase chain reaction. Diagnosing Microbiology and Infectious Disease 2006; 54: 37-43.

12. Singh S. New developments in diagnosis of leishmaniasis. Indian Journal of Medical Research 2006; 123: 311-30

13. Tordini G, Giaccherini R, Pacenti L, Miracco C, Zazzi M, Zanelli G. Cutaneous leishmaniasis: usefulness of PCR on paraffin-embedded skin biopsies as part of routine investigation. Annals of Tropical Medicine and Parasitology 2007; 101: 745-9.

\title{
Geographical variation in admissions due to poisoning in Sri Lanka: a time series analysis
}

\author{
R Hanwella', S M Senanayake ${ }^{1}$, V A de Silva ${ }^{1}$ \\ (Index words: deliberate self harm, suicide, pesticides, Sri Lanka, poisoning)
}

\begin{abstract}
Objectives To carry out time series analyses of hospital admissions for poisoning between 1995-2008 in all districts in Sri Lanka to identify trends and geographical variations in the substances used in poisoning.

Methods Data of hospital admissions from 1995-2008 due to poisoning were obtained from the Annual Health Bulletins published by the Ministry of Health. Data were converted to annual rates per 100,000 population. Time trends in the rates of suicide and self-poisoning were calculated using univariate time series analysis.
\end{abstract}

Results All districts except Kilinochchi and Mullaitivu showed an increase in the rates of admissions due to poisoning with drugs, medicaments and biological substances. Colombo, Hambantota, Kalutara and Anuradhapura showed an exponential increase. Hambantota, Monaragala, Nuwara Eliya and Colombo show an increase in the rate of admissions after pesticide poisoning. All other districts showed a linear decrease. Admissions due to all types of poisoning showed a negative trend in Anuradhapura, Polonnaruwa, Ampara, Matale and Batticoloa districts. Other districts show a positive trend in the rate of admissions for all types of poisoning.

${ }^{1}$ Department of Psychological Medicine, Faculty of Medicine, University of Colombo, Sri Lanka.

Correspondence: VdeS, e-mail: <varunidesilva2@yahoo.co.uk>. Received 30 April and revised version accepted 22 August 2012. Competing interests: none declared. 
Conclusions Results should be viewed with caution because they are based on analysis of secondary data. Although the rate of suicides has reduced since 1995, admissions due to self poisoning have increased in almost all districts. While pesticide poisoning is becoming less, there is a gradual shift to the use of drugs and medicaments in self poisoning. Poisoning with drugs, medicaments and biological substances are increasing both in urban and rural areas.

Ceylon Medical Journal 2012; 57: 152-158

\section{Introduction}

Methods of self harm in Sri Lanka have changed with time. Before 1960, hanging was the commonest method of suicide in Sri Lanka. In the 1960s ingestion of acetic acid became the commonest method used [1]. Since the 1970s the main mode of suicide has been ingestion of pesticides [2].

Analysis of admissions in the Anuradhapura and Polonnaruwa hospitals in 2002 show that the most common poisons ingested were pesticides $(49 \%)$, followed by oleander seeds (34\%). Medicines and hydrocarbons (commonly kerosene) were more often taken by women than men [3]. A study carried out in southern Sri Lanka between 1990 and 2002, found that more than half of the admissions due to poisoning were due to pesticides $(61 \%)$ but poisoning with medicines $(68 \%)$ and plant products (55\%) were more common among women [4].

In Sri Lanka use of medicinal drugs in self harm was previously thought to be an urban phenomenon. This was reported in a study conducted at the National Hospital of Sri Lanka $[5,6]$. In that study the most common substance used in poisoning was medicinal drugs (68.06\%), followed by pesticides ( $20.94 \%)$, oleander seeds (6.28\%), and other poisons (4.71\%). However, more recent data suggest that medicinal drug overdose is common in other regions of the country as well. A study of hospital admissions in the Ampara district in 2007 found that agrochemicals accounted for $29.6 \%$ and medicines for $29.1 \%$ of admissions due to poisoning [7].

We have previously reported that between 1996 and 2008 the annual incidence of hospital admissions resulting from poisoning by medicinal or biological substances increased exponentially, from 48.2 to 115.4 admissions per 100,000 population. Over the same period, annual admissions resulting from poisoning with pesticides decreased from 105.1 to 88.9 per 100,000 [8].

Geographical variation in substances used for poisoning in Sri Lanka has not been explored in detail previously. Most studies are based on analysis of admissions to hospitals in a single district. Therefore we carried out time series analyses of hospital admissions for poisoning between 1995-2008 in all districts to identify trends and geographical variations in the substances used in poisoning.

\section{Methods}

Data of hospital admissions due to poisoning were obtained from the Annual Health Bulletins published by the Ministry of Health [9]. Data were collected for the period from 1995 to 2008. Estimated mid-year populations for Sri Lanka were used to convert data to annual rates. These estimates are based on the census data of 1983 and 2001 [10]. Additional population data for Batticoloa, Ampara and Jaffna districts were obtained from the Report of the Special Enumeration carried out in 2007. Rates of admissions for poisoning were calculated per 100,000 population. Between 1995 and 2000, the Ministry of Health reported the combined admissions for Vavuniya and Mannar districts and for Mullaitivu and Kilinochchi districts [9]. Therefore our analyses include the combined estimates for these districts.

Since 1997, the Ministry of Health has classified poisoning according to the 10 th revision of the International Classification of Diseases (ICD-10) [11]. It reports admissions due to poisoning under three categories: the toxic effects of pesticides (T60.0, T60.1 and T60.9); poisoning by drugs, medicaments and biological substances (T36-T50); and the toxic effects of other, 'chiefly non-medicinal' substances, including solvents, halogen derivatives, corrosives, metals, gases and food (T51-T59, T61, T62 and T63.1-T65).

Time trends in the rates of suicide and self-poisonings were calculated using univariate time series analysis. Minitab statistical software version 14.0 was used in the analysis. Data were fitted to linear, quadratic and exponential growth models. Model adequacy was tested using the mean absolute percentage error (MAPE), a measure of how much a dependent series varies from its model-predicted level. Linear trend model is described as $\mathrm{Yt}=\alpha+\beta \mathrm{t}$. The exponential trend model is described as $\mathrm{Yt}=\alpha^{*} \beta^{\mathrm{t}}$. In the time series models $\alpha$ is the intercept, $\beta$ is the slope and $t$ is the time index. Mean admission rates for the period 2005 to 2008 were calculated to evaluate current rates of poisoning admissions.

\section{Results}

Change in the rate of admission due to drugs, medicaments and biological substances from 1995 to 2008 are described using time series analysis. The results of the analyses are given in table 1. All districts except Kilinochchi and Mullaitivu showed an increase in the rates of admissions due to poisoning with drugs, medicaments and biological substances over time. Districts of Colombo $[\mathrm{Yt}=24.0264 *(1.13 * * \mathrm{t})]$, Kalutara [Yt $=31.78 *(1.09 * \mathrm{t})]$, Hambantota $[\mathrm{Yt}=44.20 *(1.10 * * \mathrm{t})]$, and Anuradhapura $[\mathrm{Yt}=49.97 *(1.11 * \mathrm{t})]$ showed an exponential increase. Other districts show a linear increase.

The slope is indicative of the rate of increase. Of the districts which showed a linear increase Monaragala $[\mathrm{Yt}=$ $11.2+12.3 * t$ ], Polonnaruwa $[\mathrm{Yt}=67.4+11.1 *]$, Kurunegala 
$[\mathrm{Yt}=39.7+8.46 * \mathrm{t}]$ and Gampaha $[\mathrm{Yt}=6.74+8.21 * \mathrm{t}]$ showed steep rates of increase. Batticoloa $[\mathrm{Yt}=58.8+$ $2.05 * \mathrm{t}]$, Matale $[\mathrm{Yt}=50.3+2.81 * \mathrm{t}]$ and Nuwara Eliya $[\mathrm{Yt}=$ $18.64+3.03 * \mathrm{t}]$ had the lowest rates of increase. This is demonstrated graphically in Figure 1 which shows the time series graph comparing the trend lines for selected districts.

Mean rate of hospital admissions/100,000 population during the period 2005 to 2008 as a result of poisoning by drugs, medicaments and biological substances are given in table 2. Based on the mean value, the districts were grouped as those with low, medium and high rates of poisoning. Low rates $(<90 / 100,000)$ were reported in the districts of Nuwara Eliya (45.62), Kilinochchi and Mullaitivu (48.5), Matara (76.0), Matale (79.7), Vavuniya and Mannar (73.47), Ampara (87.27), Jaffna (89.85), Kegalle (84.39), and Badulla (82.65). Medium rates (90-130/100,000) were reported in the districts of Kalutara (91.66), Batticoloa (93.93), Galle (99.61), Kandy(100.37), Ratnapura (104.02), Colombo (106.7), Puttlam (110.37) and Gampaha (111.75). High rates $(>130 / 100,000)$ were reported in the districts of Trincomalee (136.43), Hambantota (137.04), Kurunegala (146.3), Monaragala (157.01), Anuradhapura (167.14), and Polonnaruwa (195.06).

Table 1. Time series analyses of admissions due to poisoning - 1995 to 2008

\begin{tabular}{|c|c|c|c|}
\hline District & $\begin{array}{l}\text { Drugs, medicaments and } \\
\text { biological substances }\end{array}$ & Pesticides & Total poisoning \\
\hline Colombo & $\mathrm{Yt}=24.03 *(1.13 * * \mathrm{t})$ & $\mathrm{Yt}=34.64+0.28 * \mathrm{t}$ & $\mathrm{Yt}=113.46 *(1.04 * * \mathrm{t})$ \\
\hline Gampaha & $\mathrm{Yt}=6.74+8.21 * \mathrm{t}$ & $\mathrm{Yt}=48.58-1.22 * \mathrm{t}$ & $\mathrm{Yt}=112.96 *(1.05 * * \mathrm{t})$ \\
\hline Kalutara & $\mathrm{Yt}=31.78 *(1.09 * * t)$ & $\mathrm{Yt}=67.13-2.82 * \mathrm{t}$ & $\mathrm{Yt}=159.60+3.65 * \mathrm{t}$ \\
\hline Galle & $\mathrm{Yt}=35.79+5.30 * \mathrm{t}$ & $\mathrm{Yt}=83.5-3.72 * \mathrm{t}$ & $\begin{array}{l}\mathrm{Yt}=183.6+2.42 * \mathrm{t} \\
\text { Since } \mathbf{2 0 0 3} \\
\mathrm{Yt}=250.7-9.46 * \mathrm{t}\end{array}$ \\
\hline Matara & $\mathrm{Yt}=10.74+4.80 * \mathrm{t}$ & $\mathrm{Yt}=88.0-4.56 * \mathrm{t}$ & $\mathrm{Yt}=146.4+3.46 * \mathrm{t}$ \\
\hline Hambantota & $\mathrm{Yt}=44.20 *(1.10 * * \mathrm{t})$ & $\begin{array}{l}\mathrm{Yt}=124.3+4.76 * \mathrm{t} \\
\text { Since } 2003 \\
\mathrm{Yt}=57.3+36.3 * \mathrm{t}\end{array}$ & $\begin{array}{l}\mathrm{Yt}=211.8+14.7 * \mathrm{t} \\
\text { Since } 2003 \\
\mathrm{Yt}=197.4+56.4 * \mathrm{t}\end{array}$ \\
\hline Anuradhapura & $\mathrm{Yt}=49.97 *(1.11 * * \mathrm{t})$ & $\mathrm{Yt}=338.0-5.62 * \mathrm{t}$ & $\mathrm{Yt}=600.6-3.88 * \mathrm{t}$ \\
\hline Polonnaruwa & $\mathrm{Yt}=67.4+11.1^{*}$ & $\mathrm{Yt}=323.0-3.12 * \mathrm{t}$ & $\begin{array}{l}\mathrm{Yt}=637.9-1.00 * \mathrm{t} \\
\text { Since } \mathbf{2 0 0 3} \\
\mathrm{Yt}=521+26.8 * \mathrm{t}\end{array}$ \\
\hline Vavuniya and Mannar & $\mathrm{Yt}=27.02+3.92 * \mathrm{t}$ & $\mathrm{Yt}=69.6+7.25 * \mathrm{t}$ & $\mathrm{Yt}=242.4+23.4 * \mathrm{t}$ \\
\hline Kilinochchi and Mullaitivu & $\mathrm{Yt}=78.1-2.35 * \mathrm{t}$ & $\mathrm{Yt}=144.6-10.84 * \mathrm{t}$ & $\mathrm{Yt}=403.8-13.10 * \mathrm{t}$ \\
\hline Jaffna & $\mathrm{Yt}=60.0+3.52 * \mathrm{t}$ & $\mathrm{Yt}=79.5-1.40 * \mathrm{t}$ & $\begin{array}{l}\text { Since } 2000 \\
\mathrm{Yt}=693.2-28.24 * \mathrm{t}\end{array}$ \\
\hline Kurunegala & $\mathrm{Yt}=39.7+8.46 * \mathrm{t}$ & $\mathrm{Yt}=225.08-3.66 * \mathrm{t}$ & $\mathrm{Yt}=434.5+4.83 * \mathrm{t}$ \\
\hline Puttlam & $\mathrm{Yt}=22.5+6.31 * \mathrm{t}$ & $\mathrm{Yt}=124.3-5.15 * \mathrm{t}$ & $\mathrm{Yt}=239.6+8.86 * \mathrm{t}$ \\
\hline Monaragala & $\mathrm{Yt}=11.2+12.3 * \mathrm{t}$ & $\mathrm{Yt}=122.8+1.01 * \mathrm{t}$ & $\mathrm{Yt}=193.5+14.4 * \mathrm{t}$ \\
\hline Badulla & $\mathrm{Yt}=27.34+5.01 * \mathrm{t}$ & $\mathrm{Yt}=160.2-0.86 * \mathrm{t}$ & $\mathrm{Yt}=233.6+8.18 * \mathrm{t}$ \\
\hline Trincomalee & $\mathrm{Yt}=40.6+7.94 * \mathrm{t}$ & $\mathrm{Yt}=128.5-3.04 * \mathrm{t}$ & $\mathrm{Yt}=226.0+12.3 * \mathrm{t}$ \\
\hline Ampara & $\mathrm{Yt}=7.65+7.00 * \mathrm{t}$ & $\mathrm{Yt}=100.9-2.04 *_{\mathrm{t}}$ & $221.8-1.16 * \mathrm{t}$ \\
\hline Batticoloa & $\mathrm{Yt}=58.8+2.05 * \mathrm{t}$ & $\mathrm{Yt}=204.2-7.35 *^{*}$ & $\mathrm{Yt}=377.8-12.67 *_{\mathrm{t}}$ \\
\hline Kandy & $\mathrm{Yt}=20.50+6.07 * \mathrm{t}$ & $\mathrm{Yt}=89.17-1.01 *_{\mathrm{t}}$ & $\mathrm{Yt}=160.5+9.38 * \mathrm{t}$ \\
\hline Matale & $\mathrm{Yt}=50.3+2.81 * \mathrm{t}$ & $\mathrm{Yt}=198.0-4.46 * \mathrm{t}$ & $\begin{array}{l}\mathrm{Yt}=355.7-0.71 *^{\mathrm{t}} \\
\text { Since } \mathbf{2 0 0 3} \\
\mathrm{Yt}=442.8-14.37 *_{\mathrm{t}}\end{array}$ \\
\hline Nuwara Eliya & $\mathrm{Yt}=18.64+3.03 * \mathrm{t}$ & $\mathrm{Yt}=86.8+2.41 *_{\mathrm{t}}$ & $\mathrm{Yt}=126.7+8.53 * \mathrm{t}$ \\
\hline Ratnapura & $\mathrm{Yt}=37.82+5.18 * \mathrm{t}$ & $\mathrm{Yt}=95.57-2.10 * \mathrm{t}$ & $\mathrm{Yt}=173.1+3.63 * \mathrm{t}$ \\
\hline Kegalle & $\mathrm{Yt}=40.87+4.13 * \mathrm{t}$ & $\mathrm{Yt}=60.14-1.37 * \mathrm{t}$ & $\mathrm{Yt}=134.5+4.59 * \mathrm{t}$ \\
\hline
\end{tabular}

* Data since 1998, included Kalmunai 
Table 2. Mean rate of admissions due to poisonings from 2005 to 2008

\begin{tabular}{|c|c|c|c|}
\hline District & $\begin{array}{l}\text { Drugs, medicaments and } \\
\text { biological substances }\end{array}$ & Pesticides & Total poisoning \\
\hline Colombo & 106.70 & 38.9 & 206.18 \\
\hline Gampaha & 111.75 & 31.45 & 209.53 \\
\hline Kalutara & 91.66 & 31.21 & 207.98 \\
\hline Galle & 99.61 & 36.29 & 209.58 \\
\hline Matara & 76.0 & 21.41 & 198.62 \\
\hline Hambantota & 137.04 & 218.76 & 452.28 \\
\hline Anuradhapura & 167.14 & 262.37 & 562.18 \\
\hline Polonnaruwa & 195.06 & 279.74 & 626.6 \\
\hline Vavuniya and Mannar & 73.47 & 173.1 & 507.03 \\
\hline Kilinochchi and Mullaitivu & 48.50 & 44.14 & 217.08 \\
\hline Jaffna & 89.85 & 65.06 & 424.70 \\
\hline Kurunegala & 146.30 & 174.5 & 487.93 \\
\hline Puttlam & 110.37 & 65.61 & 344.58 \\
\hline Monaragala & 157.01 & 137.49 & 375.20 \\
\hline Badulla & 82.65 & 139.02 & 323.90 \\
\hline Trincomalee & 136.43 & 90.22 & 382.18 \\
\hline Ampara* & 87.27 & 78.27 & 211.33 \\
\hline Batticoloa & 93.93 & 80.36 & 213.98 \\
\hline Kandy & 100.37 & 74.23 & 287.60 \\
\hline Matale & 79.70 & 129.49 & 334.18 \\
\hline Nuwara Eliya & 45.62 & 107.77 & 216.25 \\
\hline Ratnapura & 104.02 & 76.63 & 229.48 \\
\hline Kegalle & 84.39 & 42.59 & 227.40 \\
\hline
\end{tabular}

Time series analyses of rate of admission due to pesticide poisoning from 1995 to 2008 are given in Table 1. Hambantota $[\mathrm{Yt}=124.3+4.76 * t]$, Monaragala $[\mathrm{Yt}=122.8$ $+1.01 * t]$ and Nuwara Eliya $[\mathrm{Yt}=86.8+2.41 * \mathrm{t}]$ and Colombo $[\mathrm{Yt}=34.64+0.28 * \mathrm{t}]$ show an increase in the rate of admissions. All other districts showed a linear decrease in rates of admissions due to poisoning by pesticides. The rate of decline was rapid in Batticoloa $[\mathrm{Yt}=204.2-7.35 * \mathrm{t}]$, Anuradhapura $[\mathrm{Yt}=338.0-5.62 * \mathrm{t}]$ and Puttlam $[\mathrm{Yt}=124.3$ $-5.15 * \mathrm{t}]$. Figure 2 shows the time series graph comparing the trend lines for pesticide poisoning in selected districts.

Mean rate of hospital admissions during the period 2005 to 2008 due to poisoning by pesticides are given in Table 2 . High rates $(>150 / 100,000)$ were reported in the districts of Polonnaruwa (279.74), Anuradhapura (262.37), Hambantota (218.76), Kurunegala (174.5) and Vavuniya and Mannar (173.1). Medium rates $(75-150 / 100,000)$ were reported in the districts of Badulla (139.02), Monaragala (137.49), Matale (129.49), Nuwara Eliya (107.77), Trincomalee (90.22), Batticoloa (80.36), Ampara (78.27) and Ratnapura (76.63) districts. Low rates $(<75 / 100,000)$ were reported in the districts of Kandy (74.23), Puttalama (65.61), Jaffna (65.06), Kilinochchi and Mullaitivu (44.14), Kegalle (42.59), Colombo (38.9), Galle (36.29), Gampaha (31.45), Kalutara (31.21) and Matara (21.41).
Time series analyses of rate of admissions due to all types of poisoning from 1995 to 2008 are given in Table 1 . The rates of admissions show a negative trend in the districts of Anuradhapura [Yt $=600.6-3.89 * \mathrm{t}]$, Polonnaruwa $[\mathrm{Yt}=637.9-1.01 * \mathrm{t}]$, Matale $[\mathrm{Yt}=355.7$ $0.71 * t]$, Ampara [221.8 - 1.16*t], and Batticoloa [Yt $=377.8$ $-12.67 * t]$. Other districts show a positive trend in the rate of admissions for all types of poisoning. However, in some districts a negative trend is observed during recent times. Galle showed a negative trend for the period 2003-2008 $[\mathrm{Yt}=250.7-9.46 * \mathrm{t}]$ and Jaffna for the period 2000-2008 $[\mathrm{Yt}=608.5-28.24 * \mathrm{t}]$. In Polonnaruwa there is a strong negative trend for the period 1995 to 2005 [Yt $=696.9$ $13.7854 * t]$ but the rate of admissions has increased sharply after that. A strong negative trend is seen in Ampara district from 1995-2005 $[\mathrm{Yt}=260.0-11.2033 * \mathrm{t}]$ and Matale since $2003[\mathrm{Yt}=442.8-14.37 * \mathrm{t}]$. A steep rise in total admissions were seen in Monaragala [Yt $=193.5+14.4 * t]$ and Trincomalee districts $[\mathrm{Yt}=226.0+12.3 * \mathrm{t}]$. In Hambantota the rate of admissions has increased markedly since $2003[\mathrm{Yt}=197.4+56.4 * t]$. Figure 4 shows the time series graph comparing the trend lines of total admissions in selected districts.

Mean rate of total poisoning admissions during the period 2005 to 2008 are given in Table 2. High rates $(>450 /$ 
100,000) were reported in Polonnaruwa (626.6), Anuradhapura (562.18), Vavuniya and Mannar (507.03), Kurunegala (487.93), Hambantota (452.28) and Jaffna (424.7). Medium rates (450-250/100,000) were reported in the districts of Trincomalee (382.18), Monaragala (375.2), Puttlam (344.58), Badulla (323.9), Matale (334.18) and Kandy (287.6). Low rates $(<250 / 100,000)$ were reported in Ratnapura (229.48), Kegalle (227.40), Killinochchi and Mullaitivu (217.08), Nuwara Eliya (216.25) Batticoloa (213.98),Ampara (211.33), Galle(209.58), Gampaha(209.53), Colombo (206.18), Kalutara (207.98) and Matara (198.62).

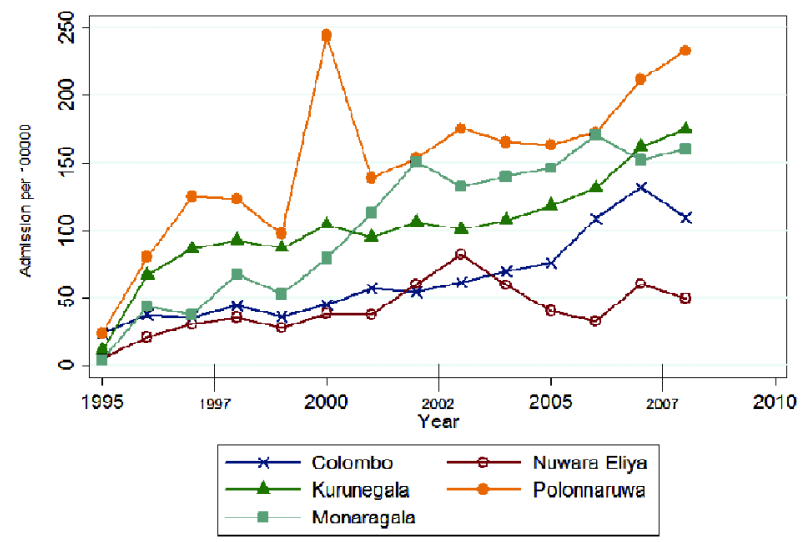

Figure 1. Time series graph of admissions due to poisoning with drugs, medicaments and biological substances in selected districts.

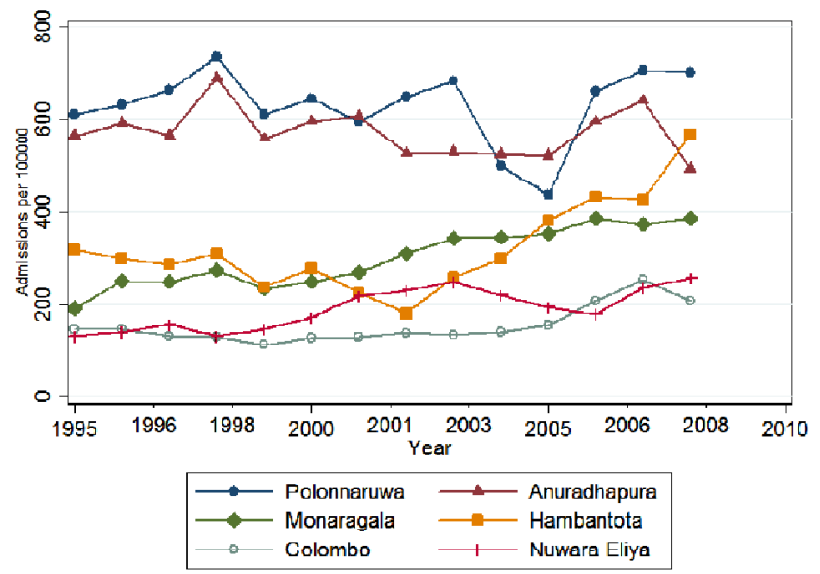

Figure 3. Time series graph of total admissions due to poisoning in selected districts.
Figure 4 shows the correlation of mean admission rate from 2005 to 2008 between drugs, medicaments and biological substances and pesticides. The figure shows that there is a positive correlation between admissions due to poisoning with pesticides and poisoning with medicaments and biological substances. Districts of Polonnaruwa, Anuradhapura, Vavuniya and Mannar, Hambantota, Kurunegala and Monaragala have high rates of admissions due to poisoning with both categories. Districts of Matara, Kegalle and Kalutara have low rates of admissions due to poisoning with both categories.

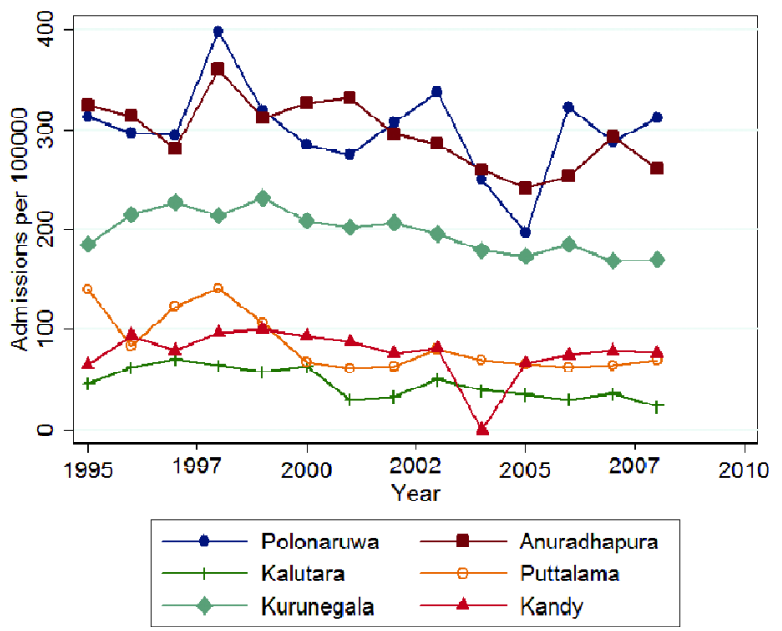

Figure 2. Time series graph of admissions due to poisoning with pesticides in selected districts.

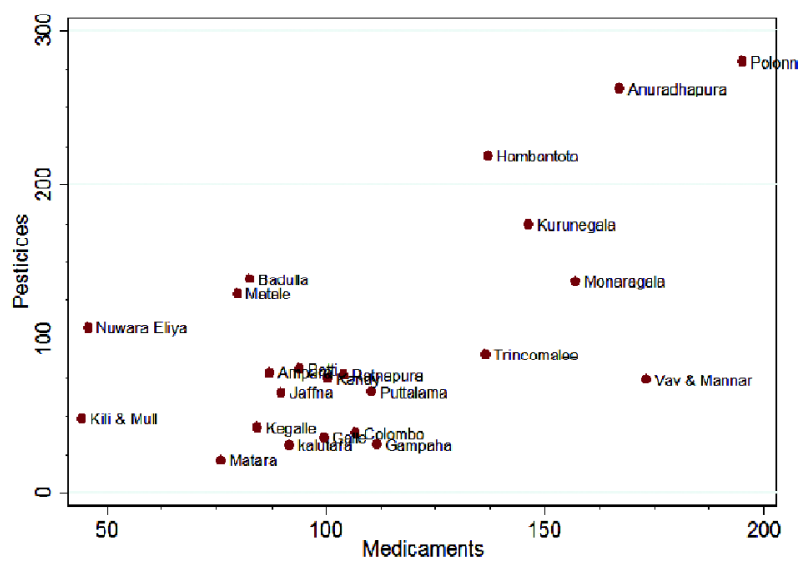

Figure 4. Correlation between rates of admission due to drugs, medicaments and biological substances and pesticide poisoning. 


\section{Discussion}

This is the first study to report time series analyses of poisoning admissions in different districts of Sri Lanka. The analyses show several important findings. The reduction in suicide rates, increase in rate of admissions due to poisoning with drugs, medicaments and biological substances and decrease in admissions due to pesticides, in the whole country was reported in a previous study [8]. The district analysis shows that the patterns of admissions vary according to districts. Results should be viewed with caution because they are based on analysis of secondary data.

During the period from 2005 to 2008, Polonnaruwa, Anuradhapura, Kurunegala and Hambantota had the highest rates of total admissions due to poisoning and the mean rates in these districts were more than double that of many districts. Almost half the admissions were due to pesticide poisoning. Districts with highest area under paddy cultivation in Sri Lanka are Anuradhapura, Kurunegala, Ampara, Polonnaruwa, Batticoloa and Hambantota [10]. Pesticides are widely available in these districts. What is surprising is that these districts also have the highest rates of poisoning with drugs, medicaments and biological substances. The rates of poisoning with these substances were higher in these districts than in the more urban districts. In Anuradhapura and Polonnaruwa, there is a change in the pattern of substances used for poisoning. There is a decline in pesticide poisoning and a rapid increase in rates of poisoning with drugs, medicaments and biological substances.

The districts with the highest percentage of population in the urban sector are Colombo (54.6\%), Gampaha (14.6\%), Ampara (19\%), Kandy (12.2\%), Galle (11.1\%) and Kalutara (10.6\%) [12]. Admissions due to all types of poisoning and pesticide poisoning were low in these urban districts. In urban districts drugs and medicaments and biological substances accounted for more than $40 \%$ of poisoning admissions. There is a steep increase in admissions due to drugs, medicaments and biological substances but the trend line is lower than in districts such as Anuradhapura, Polonnaruwa, Kurunegala and Monaragala. However, our analysis shows that overdose of medicaments in self-poisoning is not restricted to urban districts.

Many studies have reported an association between poverty and self-harm [13-17]. Our findings question this assumption. In Sri Lanka the highest percentage of poor households are in districts of Nuwara Eliya (27.5\%), Monaragala (29.2\%), Ratnapura (21.5\%), Badulla (21.0) and Kegalle (18\%) [18]. The districts with the highest level of poverty had low rates of poisoning. Low rates of total poisoning were seen in Ratnapura, Nuwara Eliya and Kegalle. Monaragala and Badulla had higher rates but these rates were much lower than in Anuradhapura and Polonnaruwa districts. The lack of a clear association between poverty and poisoning rates in Sri Lanka have been reported previously in several studies $[19,20]$.

In Sri Lanka ingestion of pesticides as a method of self-harm has become less frequent in recent years. However, self-poisoning has become more common overall, because medicinal drug overdose and poisoning by other substances classified as "chiefly non-medicinal" are more frequently used for self-harm [8]. This changing pattern of self-poisoning was observed in most districts. Reduction in the use of pesticides in self poisoning in districts such as Anuradhapura and Polonnaruwa which have high suicide rates would have contributed significantly to the overall reduction in the suicide rate. Although there is a gradual shift of substances used in self poisoning from pesticides to medicinal drugs, the steep rise in self poisoning rates in most districts is of serious concern.

In trying to understand the reasons for the increase in self poisoning, apart from area level risk factors we also need to consider individual risk factors [15]. Qualitative analysis based on in-depth interviews of patients with acute pesticide poisoning show that the poisoning attempt was often triggered by events such as a major fight with a close family member, the breaking-up of an emotional relationship, failed harvest, refusal for a new agricultural loan, a harassment episode at school, or a failed examination [19]. The high rates of self-harm in some districts may be a result of people in these districts resorting to self-harm as a method of problem solving more than in other districts.

One important limitation of the study is the accuracy of data. The results are based on analysis of secondary data. Data from the Northern and Eastern districts of the country are available only for some years and are likely to be incomplete. Population data of these districts may not be accurate because the 2001 census was not carried out in some of the districts. This could have led to errors in the calculation in rates per 100,000 population. The Ministry of Health data does not include admissions to private hospitals. However, large cross sectional studies carried out in individual districts confirm that most of the data is accurate $[3,4]$. The data does not differentiate between accidental and deliberate self-poisoning. Previous studies suggest that admissions due to accidental poisoning may be around $10 \%[4,20,21]$. Therefore it is reasonable to assume that the changing trends are mainly due to changes in patterns of self poisoning. Despite these limitations the main strength is the analysis of data which covers a long period of time. This enabled us to identify patterns in admissions over time. Many of the epidemiological studies of self harm in Sri Lanka are cross sectional and therefore have not described trends over time.

Findings of our study have several implications. Although the rate of suicides has reduced since 1995, admissions due to self poisoning have increased in most districts. While pesticide poisoning is becoming less there 
is a gradual shift to the use of drugs and medicaments in self poisoning. Poisoning with drugs, medicaments and biological substances are increasing both in urban and rural areas. Because poisoning with drugs and medicaments has much lower case fatality rates than pesticide poisoning, we have ignored the epidemic of self poisoning with drugs and medicaments. Although we may congratulate ourselves on reducing suicide rates, the increase in rates of self poisoning in almost all the districts indicates that poor coping skills have increased with more people resorting to self harm. This should be of concern and health authorities need to consider prevention of self poisoning as an important health issue.

\section{References}

1. Dissanayake S, De Silva W. Suicide and attempted suicide in Sri Lanka. Ceylon Journal of Medical Sciences 1974; 23: 10-27.

2. Gunnell D, Fernando R, Hewagama M, et al. The impact of pesticide regulations on suicide in Sri Lanka. International Journal of Epidemiology 2007; 36: 1235-42.

3. Eddleston M, Gunnell D, Karunaratne A, et al. Epidemiology of intentional self-poisoning in rural Sri Lanka. British Journal of Psychiatry 2005; 187: 583-4.

4. van der Hoek W, Konradsen F. Analysis of 8000 hospital admissions for acute poisoning in a rural area of Sri Lanka. Clinical Toxicology (Phila) 2006; 44: 225-31.

5. de Silva V, Ratnayake A. Increased use of medicinal drugs in self-harm in urban areas in Sri Lanka. Archives of Suicide Research 2008; 12 : 366-9.

6. de Silva V, Rathnayake A. Cost of the paracetamol overdose epidemic. Ceylon Medical Journal 2010; 55: 33.

7. Rajasuriya M, Asanthi MA, Ranaweera N. A descriptive study on self-poisoning in Ampara. Ceylon Medical Journal 2012; 57: 50 .

8. de Silva VA, Senanayake SM, Dias P, Hanwella R. From pesticides to medicinal drugs: time series analyses of methods of self-harm in Sri Lanka. Bulletin of the World Health Organization 2012; 90: 40-6.

9. Annual Health Bulletin. Colombo: Ministry of Health.
10. Department of Statistics. Paddy Statistics. Available from: http://www.statistics.gov.lk/agriculture/Paddy\%20Statistics/ PaddyStats.htm

11. World Health Organization. International Classification of Diseases. Geneva: World Health Organization, 1994.

12. Department of Census and Statistics. Number and percentage of population by district and sector. Available from: http:// www.statistics.gov.lk/PopHouSat/Pop_Chra.asp.

13. Gunnell DJ, Peters TJ, Kammerling RM, Brooks J. Relation between parasuicide, suicide, psychiatric admissions, and socio-economic deprivation. British Medical Journal 1995; 311: 226-30.

14. Whitley E, Gunnell D, Dorling D, Smith GD. Ecological study of social fragmentation, poverty, and suicide. British Medical Journal 1999; 319: 1034-7.

15. Burrows S, Auger N, Gamache P, et al. Influence of social and material individual and area deprivation on suicide mortality among 2.7 million Canadians: a prospective study. BMC Public Health 2011; 11: 577.

16. Agerbo E, Sterne JA, Gunnell DJ. Combining individual and ecological data to determine compositional and contextual socio-economic risk factors for suicide. Social Science and Medicine 2007; 64: 451-61.

17. Qin P, Agerbo E, Mortensen PB. Suicide risk in relation to socioeconomic, demographic, psychiatric, and familial factors: a national register-based study of all suicides in Denmark, 1981-1997. American Journal of Psychiatry 2003; 160: $765-72$.

18. Department of Census and Statistics. Poverty in Sri Lanka. Colombo: Ministry of Finance and Planning, 2009.

19. van der Hoek W, Konradsen F. Risk factors for acute pesticide poisoning in Sri Lanka. Tropical Medicine and International Health 2005; 10: 589-96.

20. Manuel C, Gunnell DJ, van der Hoek W, et al. Self-poisoning in rural Sri Lanka: small-area variations in incidence. $B M C$ Public Health 2008; 8: 26.

21. Hettiarachchi J, Kodithuwakku GC. Pattern of poisoning in rural Sri Lanka. International Journal of Epidemiology 1989; 18: 418-22. 